\title{
Diurnal course analysis of the WRF-simulated and observation-based planetary boundary layer height
}

\author{
H. Breuer ${ }^{1}$, F. Ács ${ }^{1}$, Á. Horváth ${ }^{2}$, P. Németh ${ }^{3}$, and K. Rajkai ${ }^{4}$ \\ ${ }^{1}$ Eötvös Loránd University, Department of Meteorology, 1117, Pázmány P. s. 1/a, Budapest, Hungary \\ ${ }^{2}$ Hungarian Meteorological Service, 8600 Vitorlás utca 17, Siófok, Hungary \\ ${ }^{3}$ Hungarian Meteorological Service, Marcell György Observatory, P.O. Box 39, 1675 Budapest, Hungary \\ ${ }^{4}$ Institute for Soil Sciences and Agricultural Chemistry, Centre for Agricultural Research, Hungarian Academy \\ of Sciences, 1022 Herman Ottó 15, Budapest, Hungary
}

Correspondence to: H. Breuer (bhajni@ nimbus.elte.hu)

Received: 15 January 2014 - Revised: 18 July 2014 - Accepted: 21 July 2014 - Published: 19 August 2014

\begin{abstract}
Weather Research and Forecasting (WRF) single-column model simulations were performed in the late summer of 2012 in order to analyse the diurnal changes of the planetary boundary layer (PBL). Five PBL schemes were tested with the WRF. From the radiometer and wind-profiler measurements at one station, derived PBL heights were also compared to the simulations. The weather conditions during the measurement period proved to be dry; the soil moisture was below wilting point 85 percent of the time. Results show that (1) simulation-based PBL heights are overestimated by about 500-1000 $\mathrm{m}$ with respect to the observation-based PBL heights, and (2) PBL height deviations between different observation-based methods (around $700 \mathrm{~m}$ in the midday) are comparable with PBL height deviations between different model schemes used in the WRF single-column model. The causes of the deviations are also discussed. It is shown that in the estimation of the PBL height the relevance of the atmospheric profiles could be as important as the relevance of the estimation principles.
\end{abstract}

\section{Introduction}

In the last decade the importance of planetary boundary layer (PBL) modelling has increased since high-resolution models require proper description of turbulence. Up until today several PBL schemes have been implemented into the singlecolumn models (e.g. Holt and Raman, 1988; Cuxart et al., 2006; Svensson et al., 2011) or in numerical weather (e.g. Steeneveld et al., 2008; Shin and Hong, 2011; Xie et al., 2012) or climate (e.g. Engeln and Teixeira, 2013) prediction systems. In spite of growing interest, studies focusing on the daily cycle of PBL height are rare (e.g. Hernández-Ceballos et al., 2012). This study intends to bridge this gap giving a detailed analysis of the daily cycle of PBL height in a hot summer period during 2012 in the Carpathian Basin. Observed and Weather Research and Forecasting (WRF)-simulated atmospheric profiles together with different PBL height estimating methods are used and compared in evaluating the diurnal course.

\section{Model}

The simulations were carried out with the WRF 3.4.1 (Skamarock et al., 2008) single-column model (SCM). The SCM was used in a $1 \mathrm{~km}$ domain with 60 levels. Simulation time was $48 \mathrm{~h}$, with a $5 \mathrm{~s}$ time step, from which the last $24 \mathrm{~h}$ were analysed. This model setup was performed for each day during the analysis. The Noah LSM (Chen and Dudhia, 2001) was used as the land surface scheme with four soil layers. The following main physical parameterisations were used: RRTM (rapid radiative transfer model) (Mlawer et al., 1997) for radiation transfer, WSM (WRF Single Moment) five-class for cloud microphysics (Hong et al., 2004), and the cumulus convection was calculated explicitly. The atmosphere of the SCM model was initialised at 00:00 UTC by radiosounding measurements. Advection is calculated as the model uses a $3 \times 3$ grid, but only the middle grid represents the results. Measurement-driven or 3-D-model-driven advection forcing was turned off. In the model the wind component 


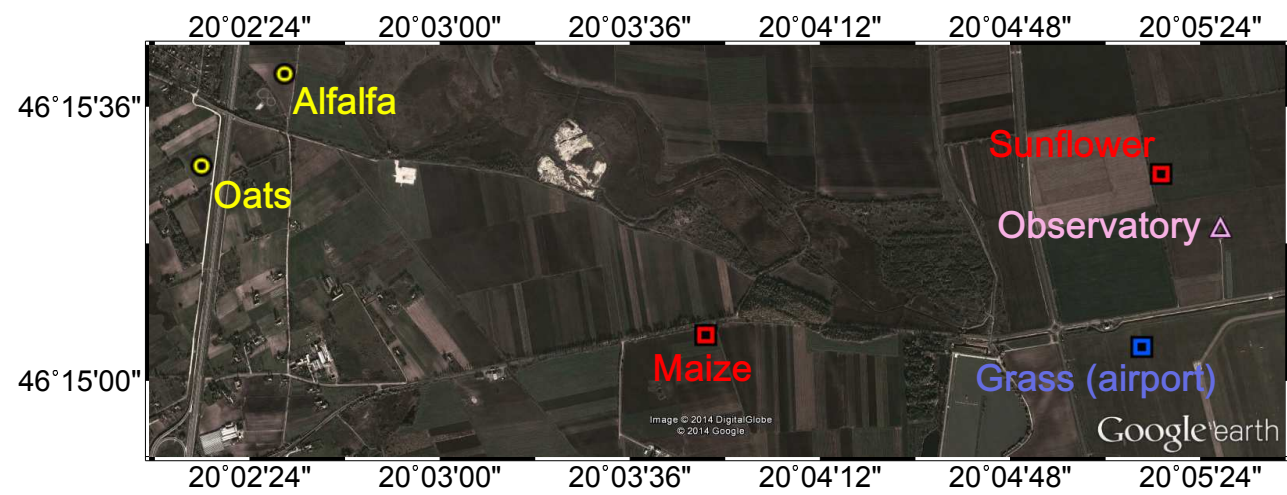

Figure 1. Location of the upper air observatory and the soil measurement sites.

tendencies and advection calculation are based on Ghan et al. (2000) following the work of Randall and Cripe (1999). As such, an upstream advection scheme is used in the model, in which the tendencies are determined with an advective timescale defined as the ratio of horizontal domain size and average measured/initial wind speed. Without outside wind forcing, this advective time scale is responsible for the wind and advection tendency. The required soil temperature was taken from the Global Forecast System. At the same time measurements were used for soil moisture as no measurements were available there.

\section{Measurements}

Radiometer and wind-profiler measurements were also used in evaluating the diurnal course of PBL height. The lowest measurement height of the wind profiler is around $154 \mathrm{~m}$. Data are available at every next $220 \mathrm{~m}$ until a height of 3$4 \mathrm{~km}$. The radiometer measurements are set to every $50 \mathrm{~m}$ until a height of $500 \mathrm{~m}$. From there to a height of $2000 \mathrm{~m}$, the measurement step is doubled, and from 2000 to $10000 \mathrm{~m}$ the step is $250 \mathrm{~m}$. Radiosonde measurements at 00:00 UTC for initialising the SCM were also conducted at the observatory operated by the Hungarian Meteorological Service. Soil moisture measurements were conducted at depths of 10-40 and $40-70 \mathrm{~cm}$ in the vicinity of the observatory at five sites (Fig. 1). At the sites marked by a circle, the soil texture is sand, and at the others it is loam. All of the sites had different cultivations: oat, alfalfa, maize, sunflower and grass (maximum leaf area index: $3,2,3.5,2.5$ and $2 \mathrm{~m}^{2} \mathrm{~m}^{-2}$, respectively). All measurements refer to the period 6 July-8 October 2012. The area around observatory was exceptionally dry until mid-September; the soil moisture was usually below wilting point except on about 10 days when local showers occurred at various sites.

\section{PBL schemes}

\subsection{WRF single-column model}

Using the SCM, five fundamentally different schemes were tested (Table 1). The Yonsei University (YSU, Hong et al., 2006; Hong, 2010) model and the Asymmetric Convective Model 2 (ACM2, Pleim, 2007) are mainly non-local mixing schemes, but the latter changes the calculations in stable conditions to local mixing. In both models, the same bulk Richardson number formalism is used, but the approaches are somewhat different. The critical Ri number in the case of YSU is 0.25 under stable and 0 under unstable conditions, while in the ACM2 it is defined as 0.25. Also in case of YSU the whole atmospheric profile is searched through for the critical values, while in case of ACM2 in unstable conditions the bulk Ri method is only used over the entrainment layer. The Mellor-Yamada-Janjić (MYJ, Janjić, 1990, 2002), the quasi-normal scale elimination (QNSE, Sukoriansky et al., 2005) and the Bougeault-Lacarrère (BouLac, Bougeault and Lacarrère, 1989) schemes predict the turbulent kinetic energy (TKE) in every model level and step and have a 1.5-order closure theory in the treatment of turbulence. The QNSE is based on the MYJ scheme but has improved mixing in stable conditions. In the MYJ and QNSE models the PBL height is defined where the turbulence disappears. This is determined from TKE, where the critical TKE drops below $0.202 \mathrm{~m}^{2} \mathrm{~s}^{-2}$. In the BouLac scheme, a more measurement-oriented approach, the parcel method is used to define the PBL height.

\subsection{PBL height estimation from measurements}

The estimation of PBL height has many forms depending on the measurements available (Seibert et al., 1997). Five methods were applied to radiometric and wind-profiler measurements in order to check variability of the estimations (Table 2). Methods applied based on the calculation of potential temperature $(\Theta)$ are André and Mahrt (1982) - hereinafter PTMG - and, naturally, the parcel method. Based on the turbulent nature of the mixing layer, the bulk Richardson 
Table 1. Main physical features of the PBL parameterisations used in the WRF-SCM model (YSU - Yonsei University, MYJ - MellorYamada-Janjić, QNSE - quasi-normal scale elimination, ACM2 - Asymmetric Convective Model 2, BouLac - Bougeault-Lacarrère).

\begin{tabular}{|c|c|c|c|c|}
\hline $\begin{array}{l}\text { Scheme } \\
\text { abbreviations }\end{array}$ & Mixing & $\begin{array}{r}\text { Order of } \\
\text { closure }\end{array}$ & $\begin{array}{l}\text { PBL height } \\
\text { determination }\end{array}$ & $\begin{array}{l}\text { Critical } \\
\text { value }\end{array}$ \\
\hline YSU & non-local & 1 & bulk Ri & $\begin{aligned} \text { bulk Ri } i_{\text {cr }} & =0.25-\text { stable } \\
\text { bulk Ri } & =0-\text { unstable }\end{aligned}$ \\
\hline MYJ & local & 1.5 & TKE & $\mathrm{TKE}_{\mathrm{cr}}=0.202 \mathrm{~m}^{2} \mathrm{~s}^{-2}$ \\
\hline QNSE & local & 1.5 & TKE & $\mathrm{TKE}_{\mathrm{cr}}=0.202 \mathrm{~m}^{2} \mathrm{~s}^{-2}$ \\
\hline ACM2 & $\begin{array}{l}\text { non-local in unstable, } \\
\text { local in stable conditions }\end{array}$ & 1 & bulk Ri & bulk $\mathrm{Ri}_{\mathrm{cr}}=0.25$ \\
\hline BouLac & local & 1.5 & parcel method & - \\
\hline
\end{tabular}

Table 2. Basic characteristics of the PBL height estimations applied to the measurements (PTMG - maximum gradient of potential temperature, MW - Matyasovszky and Weidinger (1998), RI - critical bulk Richardson number, SNR - maximum of signal-to-noise ratio).

\begin{tabular}{lll}
\hline $\begin{array}{l}\text { Scheme } \\
\text { abbreviations }\end{array}$ & $\begin{array}{l}\text { PBL height } \\
\text { determination }\end{array}$ & $\begin{array}{l}\text { Critical } \\
\text { value }\end{array}$ \\
\hline PTMG & $\begin{array}{l}\text { potential } \\
\text { temperature }\end{array}$ & $\begin{array}{l}\text { maximum } \\
\text { gradient }\end{array}$ \\
\hline $\begin{array}{l}\text { Parcel } \\
\text { method }\end{array}$ & $\begin{array}{l}\text { potential } \\
\text { temperature }\end{array}$ & $\Theta=\Theta_{\text {surface }}$ \\
\hline MW & $\begin{array}{l}\text { virtual } \\
\text { temperature } \\
\left(T_{\mathrm{V}}\right)\end{array}$ & $\begin{array}{l}\text { grad } T_{\mathrm{V}} \\
\text { grad } T_{\mathrm{V}} \text { at PBL top } \\
=0.008 \mathrm{~K} \mathrm{~m}^{-1}\end{array}$ \\
\hline RI & bulk Ri number & bulk $\mathrm{Ri}_{\mathrm{cr}}=0.25$ \\
\hline $\begin{array}{l}\text { SNR- } \\
\text { lability }\end{array}$ & $\begin{array}{l}\text { signal-to- } \\
\text { noise ratio }\end{array}$ & maximum of SNR \\
\hline
\end{tabular}

number $\left(\mathrm{Ri}_{\text {bulk }}\right)$ was also estimated for defining PBL height, where the critical value was chosen as 0.25 . Apart from these methods, a virtual temperature-based method (Matyasovszky and Weidinger, 1998, hereinafter: MW method) was also chosen. In this case the PBL height is defined where the average gradient of virtual temperature in the PBL is equal to $0.0095 \mathrm{~K} \mathrm{~m}^{-1}$ and the gradient at the PBL top is equal to $0.008 \mathrm{~K} \mathrm{~m}^{-1}$. The constants were statistically derived from radiosounding measurements. The wind-profiler measurements allowed the use of height-corrected (Lee and Kawai, 2011) signal-to-noise ratio (SNR) to define the top of the PBL as the maximum of SNR (Angevine et al., 1994). This method was modified when stable stratification was found with radiometric measurements; the maximum was searched for only as long as the SNR increased with height.

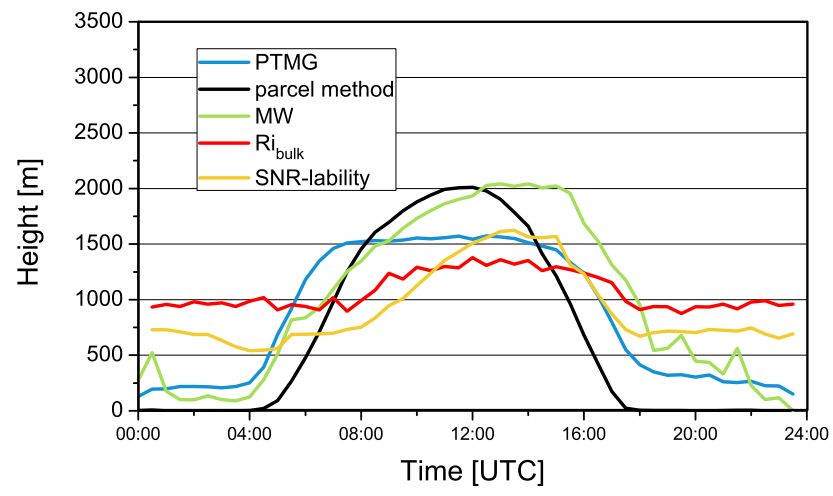

Figure 2. Average (July-September, 2012) diurnal course of PBL height derived from wind-profiler and radiometer measurements.

\section{Results}

\subsection{Averaged diurnal PBL heights}

Considering the 3-month averages of diurnal course, methods incorporating potential temperature gradient and RI show a plateau-like behaviour (Fig. 2). In those cases the maximum PBL height changes between 1200 and $1500 \mathrm{~m}$ for several hours with minimal changes. The gradual increment and sudden change are obtained from stratificationdependent SNR and the MW (Matyasovszky and Weidinger, 1998) method. The highest average PBL height from measurements is around $2000 \mathrm{~m}$ in the case of the MW and parcel method. While the parcel method gives a bell-shaped curve with a maximum at 12:00 UTC, with the MW and SNR methods this is found at around 14:00 UTC. Between the two most used methods (RI and parcel), the difference is about $600 \mathrm{~m}$ on average. The greatest increasing rate in PBL height evolution is found between 04:00 and 05:00 UTC with the PTMG and MW method, followed by the parcel method at around 06:00 UTC, the RI and the SNR method at 08:00 UTC.

The PBL height estimations obtained by WRF-SCM (Fig. 3) can be divided into two groups: one group is formed by MYJ and QNSE while the other by YSU, ACM2 and BouLac. MYJ and QNSE estimate the PBL height about 


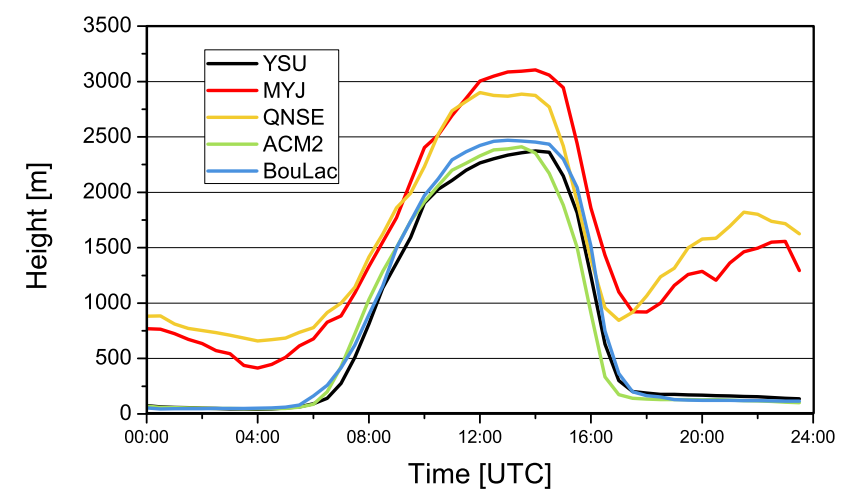

Figure 3. Average (July-September, 2012) diurnal course of PBL height using the WRF-SCM model.

$500 \mathrm{~m}$ higher than the other schemes during daytime. MYJ and QNSE are also somewhat different: these differences reach about $200 \mathrm{~m}$ around 14:00 UTC, and they are still greater between 14:30 and 16:30 UTC. Note that the differences between the two groups are greater in the nighttime than in the daytime period.

\subsection{The importance of atmospheric profiles and the estimation principles}

The scatter of PBL height diurnal courses, irrespective of simulations or observations used, is considerably high: around noon between 1300 and $3000 \mathrm{~m}$, in the midnight between few tens of metres and about $1500 \mathrm{~m}$. These enormous variations are caused by both the differences in the estimation principles and the differences in the atmospheric profiles used. The relevance of atmospheric profiles will be demonstrated in the comparison of measurement/MYJ/YSU potential temperature profiles (Fig. 4), while the relevance of the estimation principles used in different methods will be shown comparing the TKE/Ri profiles (Fig. 5). Considering the profile of $\Theta$ it can be said that the simulations were warmer at the surface with about $4 \mathrm{~K}$, which is not surprising given the conditions of the simulations. However the measured profile shows about a $3.5 \mathrm{~K}$ decrease in the surface layer which is about $300 \mathrm{~m}$ thick, while in simulation the decrease is only $0.5 \mathrm{~K}$ in the same distance. Furthermore, while in the simulations, the profile barely changes in the mixed layer, the measurements show considerable fluctuation. The $\Theta$ profile shows a stable stratification from around 1300, 2500 and $2900 \mathrm{~m}$ in case of measurement and the simulations (YSU, MYJ), respectively. The PBL height estimated with the parcel method is 1650,2130 and $2488 \mathrm{~m}$, respectively. However the model simulations put the PBL height to 2188 and $3087 \mathrm{~m}$ in case of YSU and MYJ because the determination principle is different (Fig. 5). In Fig. 5, the calculated bulk Ri number and TKE profiles can also be seen for the YSU and MYJ simulation. Up until about $2300 \mathrm{~m}$ the Ri profile shows a weak turbulence where it reaches $\mathrm{Ri}_{\mathrm{cr}}=0$. Even though a

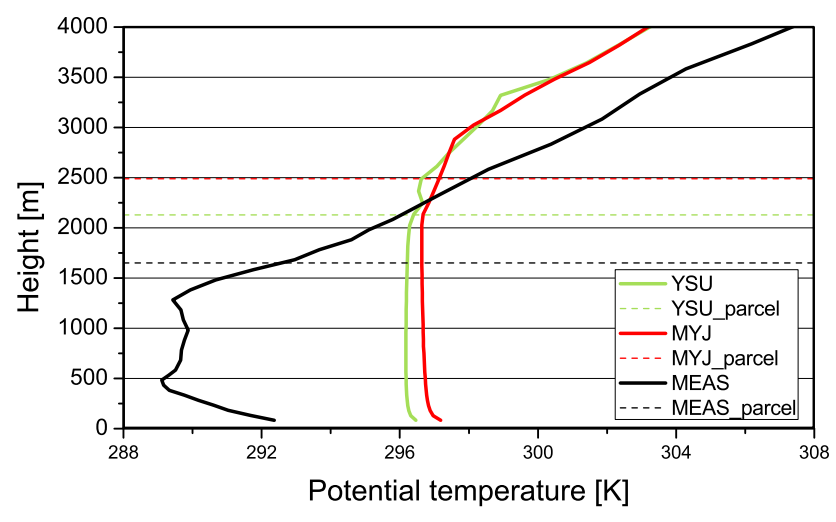

Figure 4. Measured and simulated potential temperature profile and parcel method estimated PBL heights (dashed lines) on 17 July 2012 at 12:00 UTC.

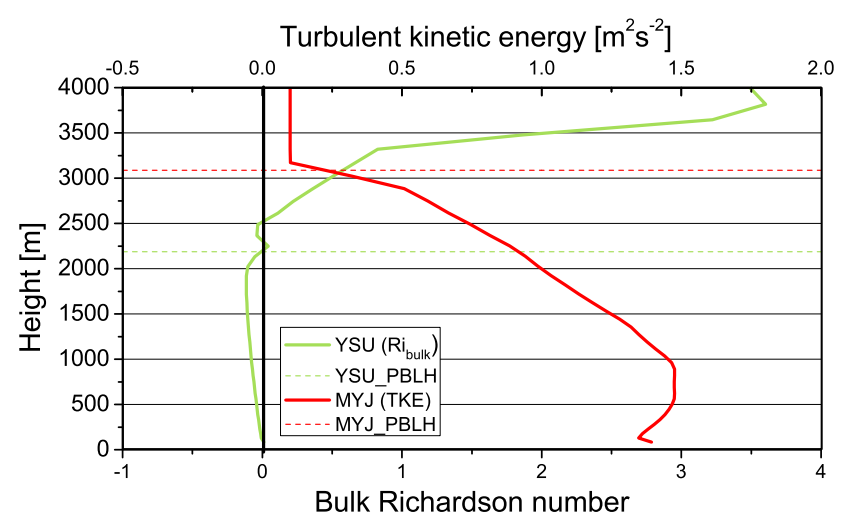

Figure 5. Simulated turbulent kinetic energy (MYJ) and calculated bulk Richardson number (YSU) profile and simulated PBL heights (dashed lines) on 17 July 2012 at 12:00 UTC.

small mixing can be found in the next $200 \mathrm{~m}$, the Ri shows constant stable stratification from $2500 \mathrm{~m}$. In the MYJ simulations the TKE is maximal at $1000 \mathrm{~m}$ and decreasing from there until about $3000 \mathrm{~m}$. In studies where seasonal or annual averages are considered, usually the average YSU PBL heights are higher than the MYJ ones (e.g. Hu et al., 2010; Coniglio et al., 2013). In the CASES-99 campaign for stably stratified, mostly cloudless days, the results are the same (Svensson et al., 2011) with SCM models, but the results are on the contrary when an unstable day is chosen (Shin and Hong, 2011) in a full WRF system. In our simulations most of the days were cloudless and unstably stratified. On days when the atmosphere was stably stratified, the YSU simulations gave higher PBL heights than the MYJ. Therefore we suppose that the differences are a result of different atmospheric stratification. 


\section{Conclusions}

PBL height diurnal variations were estimated at the observatory of the Hungarian Meteorological Service from radiometer and wind-profiler measurements as well as by the WRF-SCM model. Three-month diurnal averages were calculated over the summer drought period. The main results are as follows: (1) around noon, the simulation-based PBL heights (range: $2400-3000 \mathrm{~m}$ ) were always higher than the observation-based PBL heights (range: 1300-2000 m), which can be a result of the difference between the measured and the simulated temperatures. (2) Around noon, the scatter of the PBL heights obtained by observation-based methods (Fig. 2, about $700 \mathrm{~m}$ ) is comparable with the scatter of the PBL heights obtained by simulation-based methods (Fig. 3, 500-700 m). (3) The enormous scatter of PBL height diurnal courses is generated by the differences between the estimation principles and by the differences between the atmospheric profiles estimated by simulation or observation tools. The results of the analysis suggest that the atmospheric profile differences could be as important as the estimation principle differences.

Acknowledgements. The project is supported by the Hungarian Scientific Research Found (OTKA K-81432). The authors also thank István Aszalos for his help with the radiometer data.

Edited by: G.-J. Steeneveld

Reviewed by: three anonymous referees

\section{References}

André, J. C. and Mahrt, L.: The nocturnal surface inversion and influence of clear-air radiative cooling, J. Atmos. Sci., 39, 864 $878,1982$.

Angevine, W. M., White, A. B., and Avery, S. K.: Boundary layer depth and entrainment zone characterization with a boundarylayer profiler, Bound.-Layer Meteorol., 68, 375-385, 1994.

Bougeault, P. and Lacarrère, P.: Parameterization of orographyinduced turbulence in a mesobeta-scale model, Mon. Weather Rev., 117, 1872-1890, 1989.

Chen, F. and Dudhia, J.: Coupling an advanced land surfacehydrology model with the Penn State-NCAR MM5 modeling system. Part I: Model implementation and sensitivity, Mon. Weather Rev., 129, 569-585, 2001.

Coniglio, M. C., Correia, J., Marsh, P. T., and Kong, F.: Verification of convection-allowing WRF model forecasts of the planetary boundary layer using sounding observations, Weather Forecast., 28, 842-862, 2013.
Cuxart, J., Holtslag, A. A. M., Beare, R. J., Bazile, E., Beljaars, A., Cheng, A., Conangla, L., Ek, M., Freedman, F., Hamdi, R., Kerstein, A., Kitagawa, H., Lenderink, G., Lewellen, D., Mailhot, J., Mauritsen, T., Perov, V., Schayes, G., Steeneveld, G.-J., Svensson, G., Taylor, P., Weng, W., Wunsch, S., and Xu, K.-M.: Singlecolumn model intercomparison for a stably stratified atmospheric boundary layer, Bound.-Layer Meteorol., 118, 273-303, 2006.

Ghan, S., Randall, D., Xu, K.-M., Cederwall, R., Cripe, D., Hack, J., Iacobellis, S., Klein, S., Krueger, S., Lohmann, U., Pedretti, J., Robock, A., Rotstayn, L., Somerville, R., Stenchikov, G., Sud, Y., Walker, G., Xie, S., Yio, J., and Zhang, M.: A comparison of single column model simulations of summertime midlatitude continental convection, J. Geophys. Res., 105, 2091-2124, 2000.

Hernández-Ceballos, M. A., Adame, J. A., Bolivar, J. P., and de la Morena, B. A.: The performance of different boundary-layer parameterisations in meteorological modelling in a southwestern coastal area of the Iberian Peninsula, ISRN Meteorol., Vol. 2012, 983080, 13 pp., 2012.

Holt, T. and Raman, S.: A review and comparative evaluation of multilevel boundary layer parameterizations for first-order and turbulent kinetic energy closure models, Rev. Geophys., 26, 761780, 1988

Hong, S.-Y.: A new stable boundary-layer mixing scheme and its impact on the simulated East Asian summer monsoon, Q. J. Roy. Meteorol. Soc., 136, 1481-1496, 2010.

Hong, S.-Y., Dudhia, J., and Chen, S. H.: A revised approach to ice microphysical processes for the bulk parameterization of clouds and precipitation, Mon. Weather Rev., 132, 103-120, 2004.

Hong, S.-Y., Noh, Y., and Dudhia, J.: A new vertical diffusion package with an explicit treatment of entrainment processes, Mon. Weather Rev., 134, 2318-2341, 2006.

Hu, X.-M., Nielsen-Gammon, J. W., and Zhang, F. Q.: Evaluation of three planetary boundary layer schemes in the WRF Model, J. Appl. Meteorol. Clim., 49, 1831-1844, 2010.

Janjić, Z. I.: The step-mountain coordinate-physical package, Mon. Weather Rev., 118, 1429-1443, 1990.

Janjić, Z. I.: Nonsingular implementation of the Mellor-Yamada Level 2.5 Scheme in the NCEP Meso model, NCEP Off. Note 437, 61 pp., NCEP, Camp Springs, Md, 2002.

Lee, S.-J. and Kawai, H.: Mixing depth estimation from operational JMA and KMA wind-profiler data and its preliminary applications: Examples from four selected sites, J. Meteorol. Soc. Japan, 89, 15-28, 2011.

Matyasovszky, I. and Weidinger, T.: Charaterizig air pollution potential over Budapest using macrocirculation types, Időjárás, 102, 219-237, 1998.

Mlawer, E. J., Taubman, S. J., Brown, P. D., Iacono, M. J., and Clough, S. A.: Radiative transfer for inhomogeneous atmosphere: RRTM, a validated correlated-k model for the longwave, J. Geophys. Res., 102, 16663-16682, 1997.

Pleim, J. E.: A combined local and nonlocal closure model for the atmospheric boundary layer. Part I: Model description and testing, J. Appl. Meteorol. Clim., 46, 1383-1395, 2007.

Randall, D. A., and Cripe, D. G.: Alternative methods for specification of observed forcing in single-column models and cloud system models, J. Geophys. Res., 104, 24527-24545, 1999. 
Seibert, P., Beyrich, F., Gryning, S. E., Joffre, S., Rasmussen, A., and Tercier, P.: Mixing height determination for dispersion modelling. In: COST Action 710 Harmonization of the preprocessing of meteorological data for atmospheric dispersion models, Final Report EUR 18195 EN, Report of Working Group 2, 121 pp., 1997.

Shin, H. H. and Hong, S. Y.: Intercomparison of planetary boundary-layer parametrizations in the WRF model for a single day from CASES-99, Bound-Layer Meteorol, 139, 261-281, 2011.

Skamarock, W. C., Klemp, J. B., Dudhia, J., Gill, D. O., Barker, D. M., Duda, M., Huang, X.-Y., Wang, W., and Power, J. G.: A description of the Advanced Research WRF Version 3. NCAR Technical Note, NCAR/Tech Notes-475+STR, 125 pp., 2008.

Steeneveld, G. J., Mauritsen, T., de Bruijn, E. I. F., de Arellano, J. V. G., Svensson, G., and Holtslag, A. A. M.: Evaluation of limited-area models for the representation of the diurnal cycle and contrasting nights in CASES-99, J. Appl. Meteorol. Clim., 47, 869-887, 2008.
Sukoriansky, S., Galperin, B., and Perov, V.: Application of a new spectral theory of stable stratified turbulence to the atmospheric boundary layer over sea ice, Bound.-Layer Meteorol., 117, 231257, 2005.

Svensson, G., Holtslag, A. A. M., Kumar, V., Mauritsen, T., Steeneveld, G. J., Angevine, W. M., Bazile, E., Beljaars, A., de Bruijn, E. I. F., Cheng, A., Conangla, L., Cuxart, J., Falk, M. J., Larson, V. E., Mailhot, J., Masson, V., Park, S., Pleim, J., and Söderberg, S.: Evaluation of the diurnal cycle in the atmospheric boundary layer over land as represented by a variety of single column models - the second GABLS experiment, Bound.-Layer Meteorol., 140, 177-206, 2011.

von Engeln, A. and Teixeira, J.: A planetary boundary layer height climatology derived from ECMWF reanalysis data, J. Climate, 26, 6575-6590, 2013.

Xie, B., Fung, J. C. H., Chan, A., and Lau, A.: Evaluation of nonlocal and local planetary boundary layer schemes in the WRF model, J. Geophys. Res., 117, D12103, doi:10.1029/2011JD017080, 2012. 